\title{
Institutional Censorship in Relation to Catholic Press during the Decline of People's Republic of Poland (1989-1990)
}

Institutional censorship within the territory of Poland was established during the Second World War: in July 1944 and was called the Department of Information and Propaganda. It was a part of the Polish Committee of National Liberation (PKWN) and its foundations were built by the officers of Glavlit, Soviet censors, invited to the country by Jakub Berman, a member of the Political Office of the Polish Workers' Party (PPR). Berman was responsible, as he explained in an interview by Teresa Torańska, for culture, education, higher education, Polish Academy of Sciences, propaganda, foreign policy, ideology and security supervision $^{1}$. Berman, loyal to Bolesław Bierut, supported Soviet methods of governing and the unconditional fulfilment of orders coming from Moscow.

After WWII, Russians created censorship institutions that copied the Soviet model in all states of the "People's democracy". In Poland, the process began after the collapse of the Warsaw Uprising in October 1944. On 3 November 1944, by order of Nikolai Bulganin, a plenipotentiary of the Soviet government at PKWN, two officers of Glavlit: Piotr Gladin and Kazimierz Jarmuż, were delegated to Poland and were entrusted with the mission to create censorship in the country that was being liberated ${ }^{2}$. The reports written by Glavlit officers indicated the plans Joseph Stalin had in store for Poland. Censors from the USSR did not expect any deviations from the Soviet models of creating the propaganda and indoctrination system. In a report of January 1945, they stated that some officers of the Ministry of Information and Propaganda (on 31 December 1944 the department was converted into a ministry) "are out of their minds" thinking that censorship is not necessary.

* Dr, e-mail: ka.kaminska@uw.edu.pl, University of Warsaw, Faculty of Journalism, Information and Book Studies, 00-310 Warszawa, ul. Bednarska 2/4.

${ }^{1}$ T. Torańska, Oni [Them: Stalin's Polish Puppets], London 1985, p. 131.

2 Т.М. Горяева, Блиикриг В Польшу іn: Исключить всякие упоминания... Очерки истории советской цензуры, Москва 1995, p. 110. On Glavlit vide: А.В. Блюм, Советская цеензура в эпоху тоталъного террора 1929-1953, Санкт-петербург 2000; T. Goban-Klas, Literacki Gułag. Gławlit, czyli najwyższe stadium cenzury, in: Piśmiennictwo - systemy kontroli - obiegi alternatywne, J. Kostecki, A. Brodzka (eds.), Warsaw 1992, vol. I, pp. 46-59. 


\section{Legal framework of institutional censorship}

Censorship received its legal framework with a half-page typescript decree of 5 July 1946 which in very general terms defined the scope of the tasks of the Main Office of Control of Press, Publications and Performances (hereinafter: GUKPPiW) ${ }^{3}$. It was only the Act on the Control of Publications and Performances, introduced on 1 October 1981, that defined the competences of the censorship institution, also giving the entity under investigation the right to appeal a decision with the Supreme Administration Court. A provision that was the main focus of the opposition was the obligation, should an author request it, to mark in the text the interventions of the control institutions stating the legal basis. The Act also changed the name of the control institution from GUKPPiW to the Main Office for the Control of Publications and Performances (GUKPiW).

It is also worth mentioning that pursuant to Art. 3 of the Act, control authorities included "regional offices for the control of publications and performances operating as a first instance entities" while the Main Office for the Control of Publications and Performances (the Main Office) was defined as a central entity the task of which was to supervise the work of control offices. Entities, according to the Act, "professionally utilising freedom of speech" could appeal the official decisions with the GUKPiW and in the event of an unsatisfactory decision issued by the Main Office, with the next instance, i.e. the Supreme Administration Court.

The tasks of the regional offices for the control of publications and performances (hereinafter: OUKPiW) included: preliminary and review control of press, non-periodic publications, ephemera, performances, radio and television shows, films, exhibitions and other means of communication (propagated via printing, images or words); providing permits for publishing daily newspapers or magazines (until 6 June 1989, after that date, only registration); providing permits for conducting press publishing or outwork activities (until 6 June 1989); providing permits for the operations of some PA systems; control of printing enterprises (since 6 June 1989 within a limited scope); halting of the publication permits (for a period from one to five years) of foreign magazines.

The decision regarding the lifting of institutional censorship was taken during the Round Table talks. A report on the activities of the Mass Media Unit of the Round Table of 22 March 1989 concluded that a prerequisite for constructing a new information order which would reflect the pluralism of opinions present in the society censorship had to be lifted. As of 6 June 1990, pursuant to the Act of

\footnotetext{
${ }^{3}$ Vide J. of L. of 1946 No. 34 Item 210.
} 
11 April 1990 on the repealing of the act on the control of publications and performances, removing the units of the control and on the change of the Press Law act, GUKPiW and OUKPiW were declared in liquidation.

\section{Article premise and source base}

The goal of the article is to present the scope of interventions of the Regional Offices for the Control of Publications and Performances in the Catholic press during the decline of the People's Republic of Poland (PRL) and the first months of the Republic of Poland, i.e. between January 1989 and April $1990^{4}$. Initial censorship was a period which preceded the Round Table talks while final censorship was the abolition of censorship, i.e. the passing of the act (11 April 1990) on the liquidation of the institutions for the control of publications and performances.

The source material for the article constitutes the files of the Main Office of Control of Press, Publications and Shows stored in the Archives of New Records (hereinafter: AAN).

The Catholic press, which after 1989 constituted a focus of academic study of various researchers, both clergymen ${ }^{5}$ and lay researchers ${ }^{6}$, was selected as the subject of the article. To avoid any terminological disputes regarding the notion of the Catholic press I have used the definition proposed by bishop Adam Lepa in which the Catholic press includes publications authorised by Church authorities for periodic publication and public dissemination for a comprehensive presentation of reality, particularly of current events and issues associated with the Church and its doctrine ${ }^{7}$. Thus, the Catholic press should meet the following criteria: have a Church assistant or cooperate with the local ordinary or have the support of the Church from which it can also receive financial subventions.

${ }^{4}$ OUKPiW had its offices in the following cities: Białystok, Bydgoszcz, Gdańsk, Katowice, Kielce, Krakow, Lublin, Łódź, Olsztyn, Opole, Poznań, Rzeszów, Szczecin, Warsaw, Wrocław, O.G. of the Republic of Poland of 1981 No. 25 Item 217. Vide also J. of L. of 1981 No. 20 Item 99.

5 A. Lepa, Prasa katolicka $w$ Polsce - szanse i zagrożenia in: Pięciolecie transformacji mediów, A. Słomkowska (ed.), Warsaw 1985; J. Chrapek, Najważniejsze zadania duszpasterskie Kościoła katolickiego w Polsce wobec środków społecznego przekazu in: Dylematy transformacji prasy polskiej (1989-1993), A. Słomkowska (ed.), Warsaw 1995, pp. 19-23.

${ }^{6}$ J.J. Bojarski, A. Gzella, Katalog prasy $i$ wydawnictw katolickich, Lublin 1994; T. Mielczarek, Między monopolem a pluralizmem. Zarys dziejów środków komunikowania masowego w Polsce w latach 1989-1997, Kielce, 1998, pp. 255-260; ibidem, Prasa Kościoła katolickiego w Polsce w latach 1989-2004 in: Media wyznaniowe w Polsce 1989-2004, E. Kossewska, J. Adamowski (eds.), Warsaw 2004, pp. 89-96.

${ }^{7}$ A. Lepa, Katalog prasy katolickiej w Polsce, Łódź 1994, p. 4. 
Even though academic literature regarding the Catholic press in the PRL and the later period is considerable, the issue of censoring it has not been widely considered by researchers. Though there has been a number of introductory articles on specific titles ${ }^{8}$, mainly „Tygodnik Powszechny", it is worth mentioning that there are no extensive studies of either preventive censorship institutions or state control of freedom of speech in Catholic periodicals ${ }^{10}$.

${ }^{8}$ Vide, e.g.: F. Szpor. Cenzura prasowa jako blokada w "dialogu kultur" w latach 1981-1990. Treści i motywacje konfiskat cenzorskich dotyczacych ZSRR na łamach katolickiego tygodnika “Gość Niedzielny" in: Polska w Rosji - Rosja w Polsce. Dialog kultur, R. Paradowski, Sz. Ossowski (eds.), Poznań 2003, pp. 161-184.

${ }^{9}$ I. Pietrzkiewicz, M. Rogoż, Prewencyjne ingerencje cenzorskie w "Tygodniku Powszechnym" na przetomie lat 40. i 50., "Rocznik Historii Prasy Polskiej” 2011, issue 1-2, pp. 134-170; M. Rogoż, "Tygodnik Powszechny" w 1949 roku w świetle wtórnych ocen cenzorów Glównego Urzędu Kontroli Prasy, Publikacji i Widowisk, "Rocznik Bibliologiczno-Prasoznawczy" 2011, issue 3, pp. 107-119; K. Kamińska, Główny Urząd Kontroli Prasy, Publikacji i Widowisk wobec Tygodnika Powszechnego na przełomie lat 50. i 60. ub. wieku, "Studia Medioznawcze" 2013, issue 4, pp. 95-112; M. Strzelecka, Cztery cenzorskie kreski - o ingerencjach Gtównego Urzędu Kontroli Prasy, Publikacji i Widowisk na tamach "Tygodnika Powszechnego" w latach 1945-1989 in: Obraz, dźwięk i smak w edukacji historycznej, S. Roszak, M. Strzelecka et al. (eds.), Toruń 2010, pp. 103-119; W. Sonczyk, Ingerencje cenzorskie w "Gazecie Wyborczej" od 8 V do 4 VI 1989 r. (próba analizy i oceny) in: Media a rok 1989. Obraz przemian i nowe zjawiska na rynku, Ł. Szurmiński (ed.), Warsaw 2010, p. 7-18.

${ }^{10}$ An exception was a small book by M. Łętowska on censorship in relation to the catholic periodical "Ład", vide M. Łętowski, Gdy lizyliśmy ustrój i godziliśmy w sojusze. Cenzura prasowa w PRL na przykładzie katolickiego tygodnika społecznego "Ead", Lublin 2010. On censorship in Poland vide, e.g.: B. Gogol, "Fabryka fatszywych tekstów". Z działalności Wojewódzkiego, Urzędu Kontroli Prasy, Publikacji i Widowisk w Gdańsku w latach 1945-1958, Warsaw 2012; Z. Romek. Cenzura a nauka historyczna w Polsce 1944-1970, Warsaw 2010, pp. 21-36; idem, Nadzieje na demokratyczna cenzure w latach 1944-1945" in: Niepiękny wiek XX, B. Brzostek, J. Eisler, D. Jarosz et al. (eds.), Warsaw 2010, pp. 329-342; Cenzura w PRL. Relacje historyków, Z. Romek (ed.), Warsaw 2000; A. Paczkowski, Cenzura 1946-1949: statystyka działalności, "Zeszyty Historyczne" 1996, vol. 116, pp. 22-57; W. Pepliński, Cenzura jako instrument propagandy PRL, in: Propaganda PRL. Wybrane problemy, P. Semków (ed.), Gdańsk, 2004, pp. 14-21; J. Adamowski, A. Kozieł, Cenzura w PRL, in: Granice wolności słowa, Kielce-Warsaw 1999, pp. 57-71; J. Drygalski, J. Kwaśniewski, (Nie) realny socjalizm, Warsaw 1992, pp. 273-305; K. Kersten, Pisma rozproszone, T. Szarota, D. Libionka (eds.), Toruń, 2005, pp. 400-406; J.M. Bates, Cenzura w epoce stalinowskiej, "Teksty Drugie" 2000, issue 1/2, pp. 95-120; J. Hera, Cenzura komunistyczna - dokumenty, "Arcana" 2002, issue 43, pp. 52-58; idem, Narodziny cenzury, "Biuletyn Instytutu Pamięci Narodowej” 2007, issue 5-6, pp. 111-118; A. Pawlicki, Kompletna szarość. Cenzura w latach 1965-1972. Instytucja i ludzie, Warsaw 2001; K. Kamińska. Poczatki cenzury, in: Rok 1948. Między polska droga a projektem uniwersalnym, M. Jabłonowski, W. Jakubowski, T. Krawczak (eds.), Warsaw 2013, pp. 225-235; P. Swacha. Cenzura komunistyczna instrumentem walki politycznej ze Stanisławem Mikołajczykiem, in: Nie traćcie wiary w lepsza przyszłość: myśl i działalność polityczna Stanisława Mikołajczyka, J. Gmitruk (ed.), Warsaw 2007, pp. 235-262; M. Woźniak-Łabieniec, Strategie literackie wobec zapisu cenzury. Czesław Miłosz w krajowej prasie i poezji w latach pięćdziesiatych, "Napis" 2009, Series XV, pp. 311-326; idem, w okresie odwilzy jako temat tabu, "Acta Universitatis Lodziensis. Folia Litteraria Polonica" 2013, issue 1, pp. 89-97; idem, Rytuat w zwierciadle cenzury: Urzad Kontroli jako strażnik kultowego obrazu władzy w poczatkach Polski Ludowej, "Napis" 2010, Series XVI, pp. 369-384. 


\section{Extent of interventions}

In 1989-1990, Regional Officers for the Control of Publications and Performances intervenedin all the mass media outlets of Poland (cf. Diagram 1): in 1989 - 1,519 times and in 1990 - 48 times, which constituted a decrease by $97 \%$. Such a drastic decrease in the number of interventions can be explained, first of all, as a result of an amendment to the Control of Publications and Performances Act in July 1981, which came into force on 6 June 1989 causing an increase in the number of publications exempt from preliminary verification and liberalising the intervention criteria. Secondly, as a result of the death throes of censorship which through political changes in Poland and the decisions made during the Round Table talks regarding abolishing it, intervention began to lose its raison d'etre. Upon the analysis of reports created during the decline of the PRL by regional level control officers, particularly after the Round Table talks and the Polish United Workers' Union's (PZPR) utter defeat in the elections, one can assume that many censors began to lose faith in the continued existence of censorship and seriously entertain the possibility of their jobs being eliminated. An important factor which must have influenced their working morale was social pressure, exerted on Prime Minister Tadeusz Mazowiecki, centring around the demand for the prompt abolition of censorship. It was best exemplified by the well-known text by Seweryn Blumsztajn entitled Po cholere toto $\dot{z} y j e$ [Why, the hell, is it still alive] published in "Gazeta Wyborcza" on the front page calling for the liquidation of the office redundant and unwelcome society ${ }^{11}$.

Diagram 1. Most commonly censored mass media in 1989

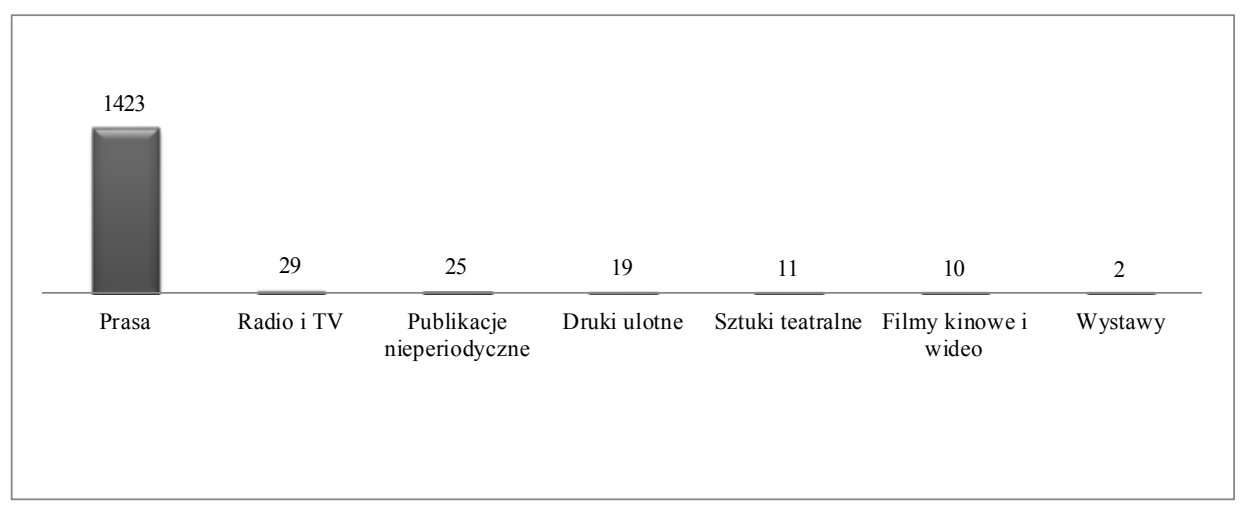

Source: own calculations based on AAN, GUKPPiW, Monthly information on performed interventions in 1989, ref. no. 2176.

${ }^{11}$ S. Blumsztajn, Po cholerę toto żyje, "Gazeta Wyborcza " 1990, issue 175, 10 I. 
The majority of censorship interventions in 1989 occurred in the press: $93.7 \%$ $(1,423$ out of 1,519$)$. Other mass media, such as radio and television, non-periodic publications, ephemera, plays, theatre and home theatre films and exhibitions remained, in terms of the extent of interventions, far behind.

Diagram 2. Most commonly censored mass media in 1990

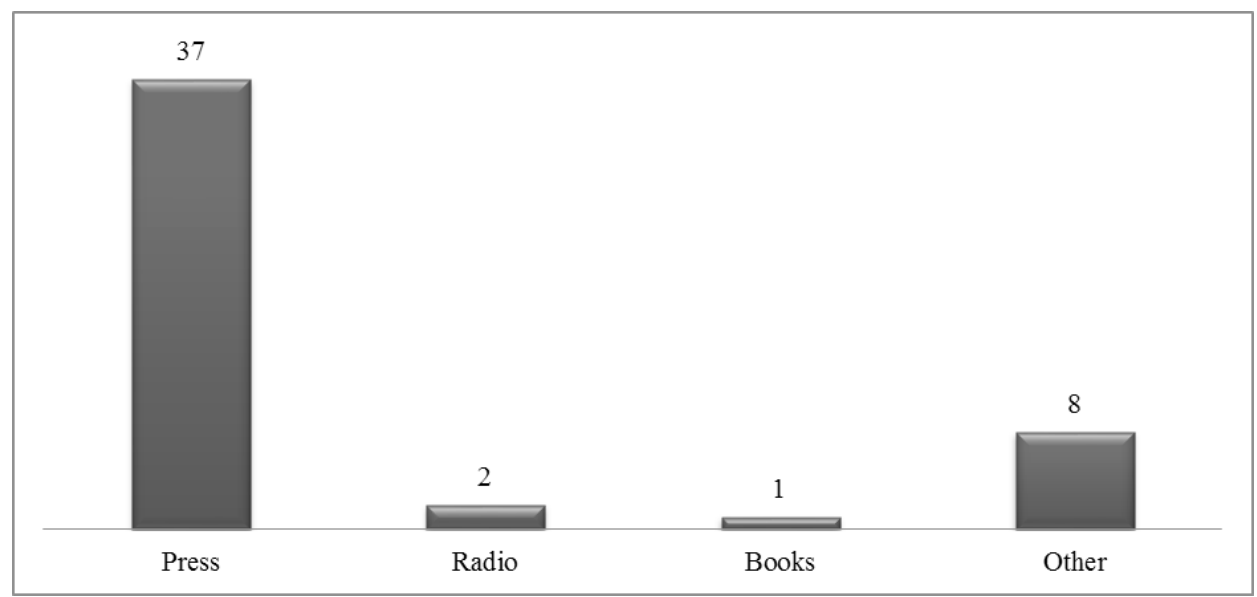

Source: own calculations based on AAN, GUKPPiW, Monthly information on performed interventions in 1990, ref. no. 2190.

The majority of censorship interventions in 1990 were made, similarly to the previous period, though to a much lesser extent, in the press. OUKPiW censors expressed their reservations towards radio programs twice (Polish Radio programs) and once towards a brochure (a book) of a pornographic nature. Unfortunately, it was not possible to establish, because of incomplete OUKPiW collective reports, other mass media outlets. 


\section{Censored catholic magazines}

Diagram 3. Number of interventions made by OUKPiW between January and December 1989 in Catholic magazines ${ }^{12}$

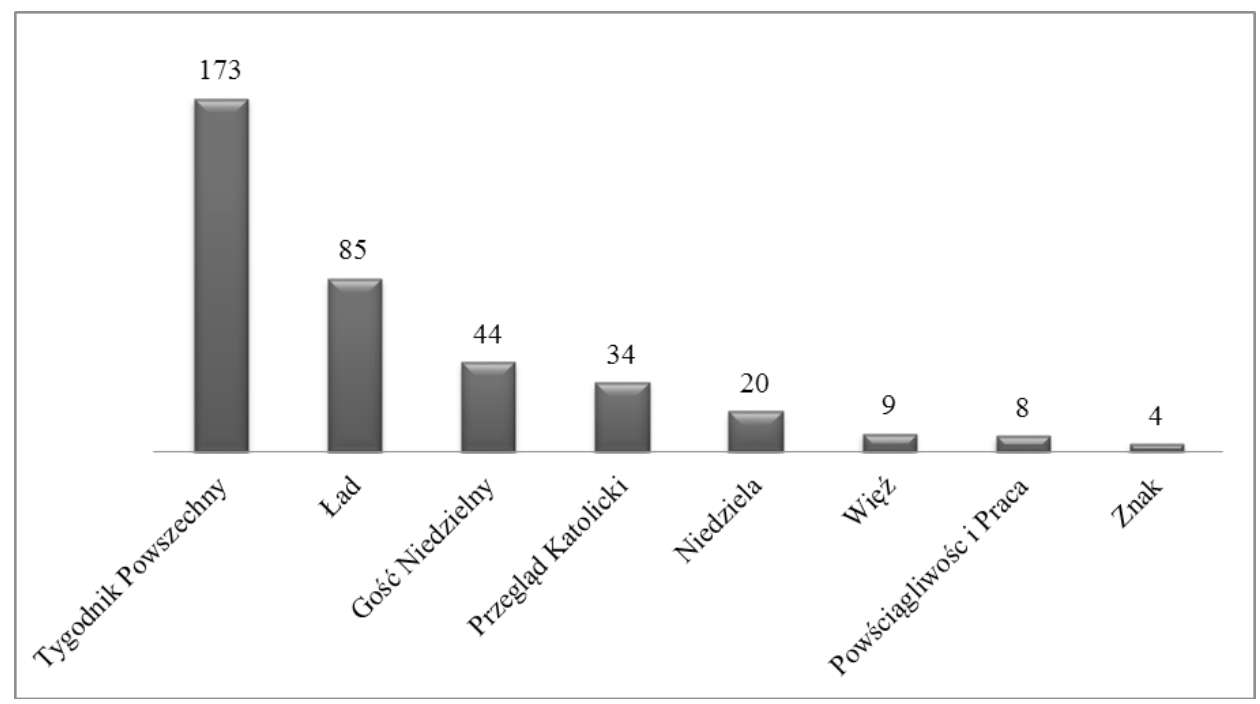

Source: own calculations based on AAN, GUKPPiW, Monthly information on performed interventions in 1989, ref. no. 2176.

The magazine which was censored the most often was "Tygodnik Powszechny", in which censors within a period of 12 months of 1989 challenged 173 fragments of texts, i.e. an average of just over 3 interventions per issue. It need be stressed that Jerzy Turowicz's weekly was subjected to the fiercest censoring among all magazines in the PRL, regardless of the changing political context ${ }^{13}$.

${ }^{12}$ Maciej Łętowski in a book on press censorship of the $\measuredangle$ ad weekly indicated a slight change in the extent of interventions stating that "Information on current interventions", which served as the basis for creating all statistical summaries, were incomplete, vide M. Łętowski, Gdy lizyliśmy ustrój i godziliśmy w sojusze. Cenzura prasowa w PRL na przyktadzie katolickiego tygodnika społecznego "Ład", Lublin, 2010, p. 150.

${ }^{13}$ In 1949-1952, the number of texts challenged in a single issue would sometimes exceed twenty, in 1957-1961 between two to 7.7, while in 1974, there were 315 interventions into its contents (on average approx. 6 interventions per issue). In the 1980s, each issue received between three to almost twelve interventions (in 1983 - 11.8 interventions, in $1988-7.6$ interventions, I. Pietrzkiewicz, M. Rogoż. Prewencyjne ingerencje cenzorskie w "Tygodniku Powszechnym" na przełomie lat 40. i 50., "Rocznik Historii Prasy Polskiej" 2011, issue 1-2, p. 149; M. Rogoż. "Tygodnik Powszechny" w 1949 roku w świetle wtórnych ocen cenzorów Głównego Urzędu Kontroli Prasy, Publikacji i Widowisk, "Rocznik Bibliologiczno-Prasoznawczy" 2011, issue 3, pp. 107-119; 
Censors themselves admitted that the work "in the Catholic division" was difficult and time-consuming, requiring extensive knowledge and focus. Thus, officers handling religious press, as one censor during a national briefing instructed, should possess "a complete understanding of the problem and political expertise"14. The problems with "Tygodnik Powszechny" were caused not only by the the very existence of preventive censorship, though it was their primary cause, but also by the attitude of the magazine's editorial board which battled censorsover every text and paragraph, unwilling to consent to any extensive interventions.

The following places were occupied by: "Ład" (77 interventions per annum) $)^{15}$, "Gość Niedzielny"16 (44), "Przegląd Katolicki”"17 (44), "Niedziela” „Niedziela”"18 (20), "Więź"19 (9), "Powściągliwość i Praca"20 (8), and "Znak"21 (4). The abovementioned periodicals constituted $26 \%$ of all censored periodicals.

K. Kamińska, Główny Urząd Kontroli Prasy, Publikacji i Widowisk wobec "Tygodnika Powszechnego" na przełomie lat 50. i 60. ub. wieku, "Studia Medioznawcze" 2013, issue 4, pp. 95-112.

${ }^{14}$ Ibidem. Annual plans and related fulfilment reports (Quarterly, semi-annual and annual reports of the activities of WUKPPiW) for 1958, ref. no. 814, p. 31.

${ }^{15} \mathrm{Ead}$, published since January 1981, initially as a bi-weekly and later as a weekly by Ośrodek Dokumentacji i Studiów Społecznych, editor: Maciej Łętowski. The magazine was licensed by the Primate of Poland card. Stefan Wyszyński used the designation "Catholic" in the subtitle; moreover, the editorial board included a Church assistant, fr. Ryszard Śliwiński. "Lad" was published, intermittently, in 1981-1985.

16 "Gość Niedzielny", a weekly established by fr. August Hlond, apostolic administrator for Upper Silesia, later the first Katowice bishop and Primate of Poland. The first issue was published on 9 September 1923. During World War II the publication of the weekly was suspended. The activities were restarted after WWII.

17 "Przegląd Katolicki", published in Warsaw since 1863 (with interruptions in 1915-1922 and 1938-1983) by the Warsaw Archdiocese.

18 "Niedziela", a periodical published intermittently since 1926 in Częstochowa, initially as a diocese periodical and as a national weekly after WWII. The issue was published on 4 April 1926.

19 "Więź", a monthly established by lay Catholic activists during the thaw period after the October 1956. The first issue was published in February 1958 and its editor-in-chief was Tadeusz Mazowiecki.

20 "Powściągliwość i Praca", a monthly issued in 1898-2006 (intermittently) by the Congregation of the Saint Michael the Archangel. It was established by blessed fr. Bronisław Markiewicz (died in 1912, blessed in 2005).

21 "Znak", a monthly issued since 1946 in Krakow by the Społeczny Instytut Wydawniczy Znak on the initiative o Jerzy Radkowski. 
Diagram 4. Number of censorship interventions in Catholic press in 1989

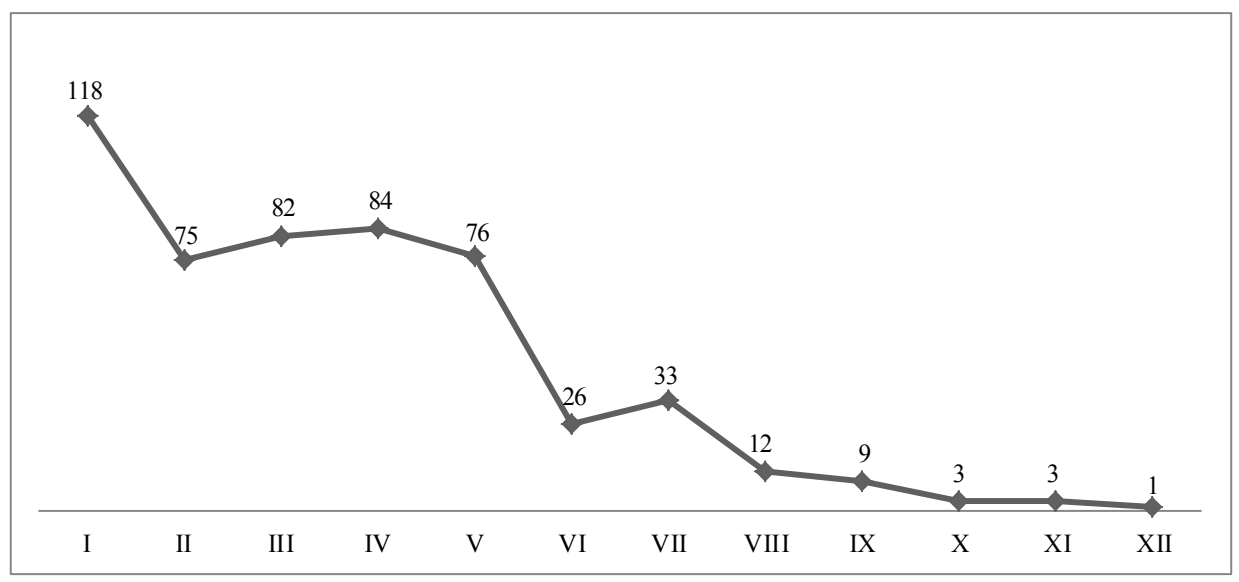

Source: my own calculations based on AAN, GUKPPiW, Monthly information on performed interventions in 1989, ref. no. 2176.

When considering the number of texts challenged by OUKPiW censors in the Catholic press, one can identify a significant drop in the number of interventions between May and June 1989: from 435 (from January to May) to 87 (between June and December). Within just two months (May and June), they dropped by 50 interventions (from 76 to 26). To offer an example, 137 interventions (out of 173) in "Tygodnik Powszechny", i.e. nearly $80 \%$, occurred within the first five months of 1989 while 81 interventions (out of 85) in the case of $\measuredangle a d$, which constituted $95 \%$ of the number of challenged press material occurring, similarly to "Tygodnik Powszechny", within the first months of the year.

Such a sudden drop in the number of censorship interventions in the Catholic press, as well as other media outlets, could be explained by two factors.

First, on 8 May 1989, the first issue of "Gazeta Wyborcza", a banner periodical of the Solidarity movement associated, at least then, with the entire worker's union community, was published. In May, the parliamentary election campaign began and, in turn, apart from Gazeta Wyborcza, other periodicals associated with the opposition, though with low-circulation and ephemeral, emerged. If until May the Catholic press was perceived as a the chief opponent endangering the monopoly of the official mass media, then more or less after the middle of the year the tendency started to shift. Opposition press with the banner title "Gazeta Wyborcza", the "child" of the Round Table, emerged in the publishing market, which by default decreased censors's interest in the Catholic press. OUKPiW censors shifted their focus to the opposition press which, quite ironically, became the leader in the race for the label of the most disobedient. 
The second factor, supplementary and no less important than the first, were the legislative changes within the Control of Publications and Performances Act, which served as the legal basis for the operations of preventive censorship in the PRL. On 6 June the Control of Publications and Performances Act of 31 July 1981 was amended. The amendment decreased the number of publications verified by censors and liberalised intervention criteria. The above-mentioned facts resulted in the decrease of interventions: from 2,528 in 1988 to 1,519 in 1989 and to 48 within the final period of censorship's existence.

Then, in 1990, during the death-throes of censorship, the number of interventions in the press decreased dramatically (see Diagram 2): down to 37 between January and April when GUKPiW ceased to exist (it was under liquidation, a process that lasted until the autumn of the same year). GUKPiW documents indicate that censors did not challenge a single text published in Catholic press. What was the reason behind such a drastic decrease in the number of interventions?

Similarl to the interventions in 1989, the drop in the following year was a result of the amendment to the Control of Publications and Performances Act of 31 July 1981, as previously mentioned.

During the decline of censorship (January-April 1990), the structure of censored themes changed, which was related to Poland's geopolitical situation. Almost all challenged texts referred to revealing state secrets (41 out of 48), which undoubtedly was associated with the Soviet troops stationed in Poland.

A that time, even though the constitution was amended changing the official name of the country and the PZPR ceased to exist, there were still Red Army troops stationed in the territory of Poland. When explaining the Cabinet's indolence in eliminating the GUKPiW, Prime Minister Tadeusz Mazowiecki said that he feared that upon elimination of preventive censorship anti-Soviet press releases would boom, which would impair the sensitive relations with the Soviet Union. He stated:

Communist states surrounded us. There were even Soviet troops stationed in Poland. The forces of the former authorities were weakened by the moral earthquake of the elections but they were nowhere near being disorganised. They had at their disposal the military, milicja [police], the Party mechanism, and secret service. It is not that difficult to imagine what would have happened, something could still had been sparked ${ }^{22}$.

${ }^{22}$ T. Mazowiecki, Sąd nad grubą kreska, "Gazeta Wyborcza” 2009, issue 214, 12 Sep. 


\section{Themes of challenged texts}

In 1989, regional offices mainly censored Catholic and Solidarity-related press. Among the periodicals associated with the opposition, censors had the most reservations about press releases published in "Gazeta Wyborcza" (119 interventions) and, to a much lesser extent, in "Tygodnik Solidarność" (29). The number of interventions in "Gazeta Wyborcza"was the highest during the election campaign, e.g. between 8 May and 4 June control officers intervened in its contents 33 times $^{23}$. In the following months, the number of challenged materials gradually decreased (in June there were 23 interventions while in December only two $)^{24}$.

The numbers of interventions made by regional offices between the January and December of 1989 in specific periodicals are presented in Diagram 3.

The thematic scope of interventions in the first six months of 1989 included $^{25}$ : politically improper, from the point of view of control authorities, evaluation of specific current events and social phenomena (basis: 59.9\% interventions), content threatening the PRL's raison d'etat, its allies, principles of foreign policy, degrading the constitutional system of the PRL (26.4\%), and content revealing state secrets regarding defence matters and armed forces (13.7\%). 48.8\% of interventions in the press were introduced in Catholic periodicals.

Within the other six months, the extent of interventions mainly included: threatening the constitutional principles of the PRL's foreign policy and its alliances (Art. 2(3)), which constituted 63\% of all interventions (189); revealing state secrets (Art. 2(5)) - 23.7\% (71); inciting an overthrowing, insulting, mocking, and degrading the PRL's system (Art. 2(2)) - 9\% (27); promoting morally detrimental content (Art. 2(10)) $-1.6 \%(5)^{26}$.

In 1990, 44 interventions were the result of revealing state secrets (Art. 2(5)) and 4 of promoting pornography (Art. 2(10)). 46 interventions occurred in the

${ }^{23}$ W. Sonczyk, op. cit., p. 7-18.

${ }^{24}$ AAN, GUKPPiW, Information on current interventions in 1989 (2-31.05), ref. no. 2167.

25 "Monthly information on introduced interventions" of 1989, i.e. reports developed at the Department of Information and Supervision (DIiN) of GUKPiW on the basis of data sent from OUKPiW, did not include legal bases for the implemented interventions, which makes it impossible to develop any detailed index of challenged material. They only included a general summary centring around three categories: "threatening alliances", "revealing state secrets", and "elimination of harmful current content". In 1989, DIiN developed only eight such reports (ref. no. 2176) covering the first eight months of the year. The remaining were abandoned probably because of a radical decrease of the number of interventions. Then in "information on current interventions" legal basis under censored material was only included since 16 June 1989, which is why it was possible to develop a detailed list of interventions. Thus, the above division into the first and the second six months' period.

${ }^{26}$ AAN, GUKPPiW, Information on current interventions for 1989, ref. no. 2169-2174. 
press, mainly in "Gazeta Wyborcza" (5), "Kurier Poranny" (4) and "Głos Pomorza" (2). There were also two interventions in other media: one in a radio program (Art. 2(5)) and one in a book (Art. 2(10)) ${ }^{27}$.

\section{Conclusions}

- The political changes which occurred in Poland in 1989-1990 considerably influenced the functioning of the GUKPiW and the OUKPiW. One of the major legislative changes of that period was the amendment of the Control of Publications and Performances Act of 29 May 1989 which limited the number of censorship interventions by approximately $70 \%$.

- The beginning of the end of institutional censorship in Poland were the Round Table talks, during which a decision was made to eliminate institutional censorship. A report on the activities of the Mass Media Unit of the Round Table of 22 March 1989 concluded that a prerequisite for constructing a new information order which would reflect the pluralism of opinions present in the society was that censorship had to be abolished ${ }^{28}$. As of 6 June 1990, pursuant to the Act of 11 April 1990 on the repealing of the act on the control of publications and performances, removing the units of the control and on the change of the Press Law act, GUKPiW and OUKPiW were declared in the process of liquidation.

- A periodical which was censored the most often within the discussed period was ,Tygodnik Powszechny”, in which censors within a period of 12 months of 1989 challenged 173 fragments of texts, i.e. an average of just over 3 interventions per issue. Jerzy Turowicz's weekly was subjected to the fiercest censoring among all magazines in the PRL, regardless of the changing political context.

- The most common reason for a censorship intervention in the press in general published during the decline of the PRL were: in 1989 - threatening the constitutional principles of the PRL's foreign policy and its alliances (Art. 2(3)) and in 1990 - revealing state secrets (Art. 2(5)).

\footnotetext{
${ }^{27}$ AAN, GUKPPiW, Information on current interventions for 1990, ref. no. 2190, 1. 2-16.

${ }^{28}$ Vide Sprawozdanie z Podzespotu ds. Środków Masowego Przekazu (22 marca 1989 r.), in: Materiały pomocnicze do najnowszej historii dziennikarstwa, A. Słomkowska (ed.), Warsaw 1992, vol. XX, p. 12-25. In January 1990, two legal drafts were submitted. The first one was developed by the Sejm deputies and presented during a session of the Sejm by Barbara Labuda and other one was developed by the government. Vide summary of the discussion about the drafts: J. Sobczak. Organy kontroli publikacji $i$ widowisk w przededniu ich zniesienia in: Media a rok 1989. Obraz przemian i nowe zjawiska na rynku, Ł. Szurmiński (ed.), Warsaw 2010, pp. 244-249. Z. Krajewska, M. Urbaniak. Życie bez cenzury, "Rzeczpospolita” 1990, issue 28, 2 Feb.
} 


\section{Bibliography}

The Central Archives of Modern Records (hereinafter: AAN), Main Office of Control of Press, Publications and Shows (hereinafter: GUKPPiW), Informacje o bieżących ingerencjach w 1989 (2-31.05), ref. no. 2167.

AAN, GUKPPiW, Informacje o bieżących ingerencjach za rok 1989, Ref. No 2169-2174.

AAN, GUKPPiW, Informacje o bieżących ingerencjach za rok 1990, Ref. No 2190, pp. 2-16.

AAN, GUKPPiW, Plany roczne i sprawozdania z ich wykonania (Sprawozdania kwartalne, półroczne i roczne z działalności WUKPPiW) za rok 1958, Ref. No 814.

Adamowski Janusz, Kozieł Andrzej, Cenzura w PRL, in: Granice wolności słowa, G. Miernik (ed.), KTN, Kielce-Warsaw 1999, p. 57-71.

Bates John, Cenzura w epoce stalinowskiej, "Teksty Drugie” 2000, issue 1/2, pp. 95-120.

Blumsztajn Seweryn, Po cholerę toto żyje, "Gazeta Wyborcza" 1990, issue 175, 10 I.

Bojarski Jerzy Jacek, Gzella Alojzy, Katalog prasy i wydawnictw katolickich, Kerygma, Lublin 1994.

Cenzura w PRL. Relacje historyków, Z. Romek (ed.), "Neriton”: Instytut Historii PAN, Warsaw 2000.

Chrapek Jan, Najważniejsze zadania duszpasterskie Kościoła katolickiego w Polsce wobec środków społecznego przekazu, in: Dylematy transformacji prasy polskiej (1989-1993), A. Słomkowska (ed.), Elipsa, Warsaw 1995.

Drygalski Jerzy, Kwaśniewski Jacek, (Nie) realny socjalizm, Wydawnictwo Naukowe PWN, Warsaw 1992, pp. 273-305.

Dz. U. 1946, No 34 item 210.

Dz. U. 1981, No 20 item 99.

Dz. U. 1981, No 20 item 99.

Goban-Klas Tomasz, Literacki Gułag. Gławlit, czyli najwyższe stadium cenzury, in: Piśmiennictwo-systemy kontroli-obiegi alternatywne, J. Kostecki, A. Brodzka (eds.), Biblioteka Narodowa, Warsaw 1992, vol. I, pp. 46-59.

Gogol Bogusław, "Fabryka fałszywych tekstów". Z działalności Wojewódzkiego, Urzędu Kontroli Prasy, Publikacji i Widowisk w Gdańsku w latach 1945-1958, Neriton, Warsaw 2012.

Hera Janina, Cenzura komunistyczna - dokumenty, “Arcana” 2002, issue 43, pp. 52-58.

Hera Janina, Narodziny cenzury, "Biuletyn Instytutu Pamięci Narodowej” 2007, issue 5-6, pp. 111-118.

Kamińska Kamila, Główny Urząd Kontroli Prasy, Publikacji i Widowisk wobec "Tygodnika Powszechnego" na przetomie lat 50. i 60. ub. wieku, "Studia Medioznawcze" 2013, issue 4, pp. 95-112.

Kamińska Kamila, Początki cenzury, in: Rok 1948. Między polska droga a projektem uniwersalnym, M. Jabłonowski, W. Jakubowski, T. Krawczak (eds.), Aspra-JR, Warsaw 2013, pp. 225-235.

Kersten Krystyna, Pisma rozproszone, oprac. T. Szarota, D. Libionka, Instytut Historii PAN, Toruń 2005, pp. 400-406.

Lepa Adam, Katalog prasy katolickiej w Polsce, Archidiecezjalne Wyd. Łódzkie, Lodz 1994.

Lepa Adam, Prasa katolicka w Polsce - szanse i zagrożenia, in: Pięciolecie transformacji mediów, A. Słomkowska (ed.), Elipsa, Warsaw 1985.

Łętowski Maciej, Gdy li̇yliśmy ustrój i godziliśmy w sojusze. Cenzura prasowa w PRL na przyktadzie katolickiego tygodnika społecznego "Ead”, Wydawnictwo KUL, Lublin 2010.

M. P. 1981 r. No 25 item 217.

M. P. 1981 r. No 25 item 217.

Mazowiecki Tadeusz, Sąd nad gruba kreska, "Gazeta Wyborcza” 2009, issue 214, 12 IX. 
Mielczarek Tomasz, Między monopolem a pluralizmem. Zarys dziejów środków komunikowania masowego w Polsce w latach 1989-1997, Wyższa Szkoła Pedagogiczna im. Jana Kochanowskiego, Kielce 1998.

Mielczarek Tomasz, Prasa Kościoła katolickiego w Polsce w latach 1989-2004, in: „Media wyznaniowe w Polsce 1989-2004, E. Kossewska, J. Adamowski (eds.), Aspra-Jr, Warsaw 2004, pp. 89-96.

Paczkowski Andrzej, Cenzura 1946-1949: statystyka działalności, "Zeszyty Historyczne” 1996, issue 116, pp. 22-57.

Pawlicki Aleksander Kompletna szarość. Cenzura w latach 1965-1972. Instytucja i ludzie, Trio, Warsaw 2001.

Pepliński Wiktor, Cenzura jako instrument propagandy PRL, in: Propaganda PRL. Wybrane problemy, P. Semków (ed)., Instytut Pamięci Narodowej - Komisja Ścigania Zbrodni Przeciwko Narodowi Polskiemu, Gdansk 2004, pp. 14-21.

Pietrzkiewicz Iwona, Rogoż Michał, Prewencyjne ingerencje cenzorskie w "Tygodniku Powszechnym" na przetomie lat 40. i 50., "Rocznik Historii Prasy Polskiej“"2011, issue 1-2, pp. 134-170.

Rogoż Michał, "Tygodnik Powszechny” w 1949 roku w świetle wtórnych ocen cenzorów Głównego Urzędu Kontroli Prasy, Publikacji i Widowisk, "Rocznik Bibliologiczno-Prasoznawczy" 2011, issue 3, pp. 107-119.

Romek Zbigniew, Cenzura a nauka historyczna w Polsce 1944-1970, Neriton: Instytut Historii PAN, Warsaw 2010.

Romek Zbigniew, Nadzieje na demokratyczna cenzurę w latach 1944-1945, in: Niepiękny wiek $X X$, B. Brzostek, J. Eisler, D. Jarosz (eds.), Instytut Historii Polskiej Akademii Nauk: Instytut Pamięci Narodowej - Komisja Ścigania Zbrodni przeciwko Narodowi Polskiemu, Warsaw 2010, pp. 329-342.

Sobczak Jacek, Organy kontroli publikacji i widowisk w przededniu ich zniesienia, in: Media a rok 1989. Obraz przemian i nowe zjawiska na rynku, Ł. Szurmiński (ed.), Aspra-JR, Warsaw 2010, pp. 244-249.

Sonczyk Wiesław, Ingerencje cenzorskie w "Gazecie Wyborczej” od 8 V do 4 VI 1989 r. (próba analizy i oceny), in: Media a rok 1989. Obraz przemian i nowe zjawiska na rynku, Ł. Szurmiński (ed.), Aspra-JR, Warsaw 2010, pp. 7-18.

Sprawozdanie z Podzespotu ds. Środków Masowego Przekazu (22 marca 1989 r.), in: Materiaty pomocnicze do najnowszej historii dziennikarstwa, A. Słomkowska (ed.), Elipsa, Warsaw 1992, vol. XX, pp. 12-25.

Strzelecka Małgorzata, Cztery cenzorskie kreski - o ingerencjach Gtównego Urzędu Kontroli Prasy, Publikacji i Widowisk na łamach "Tygodnika Powszechnego" w latach 1945-1989, in: Obraz, dźwięk i smak w edukacji historycznej, S. Roszak, M. Strzelecka (eds.), Stowarzyszenie Oświatowców Polskich, Torun 2010, pp. 103-119.

Swacha Piotr, Cenzura komunistyczna instrumentem walki politycznej ze Stanisławem Mikołajczykiem, in: Nie traćcie wiary $w$ lepsza przyszłość: myśl i działalność polityczna Stanisława Mikołajczyka, G. Janusz (ed.), Muzeum Historii Polskiego Ruchu Ludowego, Warsaw 2007, pp. 235-262.

Szpor Franciszek, Cenzura prasowa jako blokada w “dialogu kultur” w latach 1981-1990. Treści i motywacje konfiskat cenzorskich dotyczacych ZSRR na łamach katolickiego tygodnika "Gość Niedzielny", in: Polska w Rosji-Rosja w Polsce. Dialog kultur, R. Paradowski, S. Ossowski (eds.), INPiD UAM, Poznan 2003, pp. 161-184.

Torańska Teresa, Oni, Aneks, London 1985. 
Woźniak-Łabieniec Marzena, Strategie literackie wobec zapisu cenzury. Czesław Miłosz w krajowej prasie i poezji w latach pięćdziesiatych, "Napis" 2009, issue XV, pp. 311-326.

Woźniak-Łabieniec Marzena, Cenzura w okresie odwilży jako temat tabu, "Acta Universitatis Lodziensis. Folia Litteraria Polonica" 2013, issue 1, pp. 89-97.

Woźniak-Łabieniec Marzena, Rytuat w zwierciadle cenzury: Urząd Kontroli jako strażnik kultowego obrazu władzy w początkach Polski Ludowej, "Napis" 2010, issue XVI, pp. 369-384.

Блюм А.В., Советская цензура в эпоху тотального террора 1929-1953, С.-петербург СанктПетербург 2000.

Горяева Т.М., Блищкриг в Польшу, in: Исключить всякие упоминания: очерки истории советской цензуры, Москва 1995.

Kamila Kamińska-Chełminiak

\section{Institutional Censorship in Relation to Catholic Press during the Decline of People's Republic of Poland (1989-1990)}

\section{(Summary)}

The goal of the article is to present the scope of interventions by the Regional Offices for the Control of Publications and Performances in the Catholic press during the decline of the People's Republic of Poland (PRL) and the first months of the Republic of Poland, i.e. between January 1989 and April 1990. Initial censorship was a period which preceded the Round Table talks while final censorship ended with the abolition of censorship, i.e. the passing of the act (11 April 1990) on the liquidation of the institutions for the control of publications and performances. The source material for the article were the files of the Main Office of Control of Press, Publications and Shows stored in the Archives of New Records.

Keywords: censorship in the People's Republic of Poland, catholic press, the Round Table 